\title{
The Effect of Temperature on the Production by Coagulase- Positive Staphylococci of Staphylokinase and other Extracellular Substances
}

\author{
By CELIA BUNGAY \\ Sir William Dunn School of Pathology, University of Oxford
}

(Received 14 October 1960)

\section{SUMMARY}

Three strains of coagulase-positive staphylococci, grown at temperatures between $35^{\circ}$ and $43^{\circ}$, showed no significant change in mass of growth or in yield of $\alpha$-haemolysin and the Panton-Valentine (PV) leucocidin. Staphylokinase production, however, decreased by $18 \%$ (per mg. dry weight) for each degree rise in temperature. The amount of hyaluronidase produced at $37^{\circ}$ was five to eight times greater than that produced at $41^{\circ}$.

\section{INTRODUCTION}

The optimal temperature for growth of a pathogenic organism is usually that of its host. The effects of different temperatures during the growth of numerous micro-organisms has been studied. For example, toxin production by Corynebacterium diphtheriae is best at $34^{\circ}$. Escherichia coli grown at progressively higher temperatures has its generation time progressively increased (Barber, 1908). Mycobacterium ulcerans shows little or no growth above $33^{\circ}$ (MacCallum, Tolhurst, Buckle \& Sissons, 1948). Pasteurella pestis at temperatures above $32^{\circ}$ has its synthesis of metabolites markedly depressed (Hills \& Spurr, 1952). P. pseudotuberculosis, which is strongly motile and possesses good flagellar antigens at $\mathbf{2 2}^{\circ}$ loses these at $37^{\circ}$ (Preston \& Maitland, 1952). Listerella monocytogenes produces better flagellar antigens at $25^{\circ}$ than at $37^{\circ}$ (Paterson, 1939, quoting McGaughey). Type III strains of Pneumococcus which produce only local lesions in rabbits do not survive when grown at $41^{\circ}$, whereas those strains which withstand this growth temperature cause fatal infections (Enders \& Shaffer, 1936; Rich \& McKee, 1936). It was of interest, therefore, to see what effects, if any, the incubation temperature had with three strains of Staphylococcus on the crop of organisms and yield of staphylokinase, $\alpha$-haemolysin, Panton-Valentine (PV) leucocidin (Panton \& Valentine, 1932) and hyaluronidase.

\section{METHODS}

Organisms. Three coagulase-positive strains of Staphylococcus were used in these investigations: P 80, a phage-type 80 strain (from the late Dr E. S. Duthie); V 8, isolated from a case of chronic furunculosis (Gladstone \& Van Heyningen, 1957); the Oxford strain used in the assay of penicillin. The organisms for inoculation were grown on Difco heart infusion agar slopes overnight at $37^{\circ}$. These slopes were kept at room temperature and used during about 4 weeks, after which new slopes were used. 
Inoculum. In all cases a $10 \%(\mathrm{v} / \mathrm{v})$ inoculum was used, grown in the same medium and at the same temperature as in the test. An overnight culture on a Difco agar slope was inoculated into $10 \mathrm{ml}$. broth, grown overnight and diluted 1/10 in the test medium.

Production of staphylokinase, PV leucocidin and hyaluronidase. Preliminary tests showed that the same media and cultural conditions were suitable for the production of these substances, but different times of incubation were required. The medium (CCY) was Woodin's modification (Woodin, 1959) of the yeast casein medium of Gladstone \& Fildes (1940), namely: Difco Casamino acids, 20 g., Na lactate $70 \%$ syrup, 14.4 ml.; $\mathrm{Na}$ glycerophosphate, $20 \mathrm{~g}$; $\mathrm{MgSO}_{4} \cdot 7 \mathrm{H}_{2} \mathrm{O}$ solution $(\mathbf{1 6} \% \mathrm{w} / \mathrm{v})$, $0.25 \mathrm{ml}$; $\mathrm{MnSO}_{4} .4 \mathrm{H}_{2} \mathrm{O}$ solution $\left(6.4 \%\right.$, w/v), $0.125 \mathrm{ml}$; $\mathrm{FeSO}_{4} .7 \mathrm{H}_{2} \mathrm{O}$ solution $\left(0.32 \%\right.$, w/v), citric acid solution $\left(0.32 \%\right.$, w/v), $2 \mathrm{ml}$; $\mathrm{KH}_{2} \mathrm{PO}_{4}, 0.41 \mathrm{~g}$.; $\mathrm{Na}_{2} \mathrm{HPO}_{4} \cdot 2 \mathrm{H}_{2} \mathrm{O}, 3 \cdot 1 \mathrm{~g}$.; Oxoid yeast diffusate from $20 \mathrm{~g}$. (this yeast diffusate was prepared by dialysing $100 \mathrm{~g}$. yeast extract (Oxoid) dissolved in $100 \mathrm{ml}$. distilled water against $900 \mathrm{ml}$. distilled water for $24 \mathrm{hr}$. in the cold). Distilled water was added to make the final volume of the medium to 1 l. after adjustment to pH $7 \cdot 6$. The medium was distributed in $10 \mathrm{ml}$. volumes in L-tubes (Van Heyningen \& Gladstone, 1953) and autoclaved for $15 \mathrm{~min}$. at $120^{\circ}$. Cultures were shaken exposed to air in a water-bath at a known constant temperature $\left( \pm 0 \cdot 1^{\circ}\right)$ and were harvested, unless otherwise stated, at $6 \frac{1}{2} \mathrm{hr}$. for staphylokinase (time for optimal production; see Results), 14 hr. for hyaluronidase and $18 \mathrm{hr}$. for PV leucocidin.

Production of $\alpha$-haemolysin. Preliminary tests showed that $2 \%(\mathrm{w} / \mathrm{v})$ Difco heart infusion broth, without the addition of $0.2 \%(\mathrm{w} / \mathrm{v})$ agar, produced good yields of $\alpha$-haemolysin. This medium was distributed in $15 \mathrm{ml}$. volumes in $4 \mathrm{oz}$. medical flats and autoclaved at $120^{\circ}$ for $15 \mathrm{~min}$. After inoculation, the cultures were gassed with a mixture of $20 \%(\mathrm{v} / \mathrm{v}) \mathrm{CO}_{2}+80 \%(\mathrm{v} / \mathrm{v})$ air, closed with screw caps and incubated in a horizontal position in a water-bath at known temperature for $48 \mathrm{hr}$.

Estimation of growth. Growth was estimated in a Hilger Spekker spectrophotometer calibrated in terms of bacterial dry weight per ml. culture.

Harvesting of cultures. After incubation for the appropriate time, the cultures were centrifuged at $2500 \mathrm{rev} . / \mathrm{min}$. for $10 \mathrm{~min}$; the supernatant fluids were retained and used without filtration, and the deposits examined by Gram staining to test for purity. For the estimations of staphylokinase, 1/100,000 thiomersalate was added to prevent further growth.

\section{Assay of staphylokinase}

Staphylokinase was assayed on a semi-microscale, by a combining test with antibody, as follows. Glass coverslips were thoroughly cleaned in chromic acid ( $40 \mathrm{~g}$. potassium dichromate in $1 \mathrm{l}$. concentrated sulphuric acid) rinsed in tap water and distilled water and stored in ethanol until required. All tubes used for dilutions were cleaned in a similar manner. Four small wax circles were made on each coverslip and into each circle was pipetted a solution of $0.01 \%(\mathrm{w} / \mathrm{v})$ fibrinogen (Blood Products Laboratory, Lister Institute) in $0.5 \%(\mathrm{w} / \mathrm{v})$ gelatin saline $(\mathrm{pH} \mathrm{7 \cdot 6})$ using a microsyringe. To each circle was added about $0.002 \mathrm{ml}$. of a $0.2 \%(\mathrm{w} / \mathrm{v})$ solution of thrombin (Blood Products Laboratory, Lister Institute) in gelatin saline containing $0.01 \mathrm{ml}$. Hucker-Conn fibrin stain $/ \mathrm{ml}$. As each drop was added, 
the two solutions within a circle were mixed with a small glass rod. These quantities were found to provide a firm clot after incubation at $37^{\circ}$ for $10 \mathrm{~min}$. in moist chambers.

The minimum lytic dose (MLyD) of the staphylokinase preparation was first determined as follows. The culture supernatant fluid was serially diluted at $100 \%$ differences in gelatin saline. A volume of $0.01 \mathrm{ml}$. of each dilution, ranging from undiluted supernatant fluid to 1/1024, dilution, was pipetted on to a preformed fibrin clot, prepared as above, by using a microsyringe. As a control, $0.01 \mathrm{ml}$. of 1/10 dilution of a preparation of soya bean trypsin inhibitor (from Worthington Biochemical Sales Co., New Jersey) was mixed with the undiluted supernatant fluid before addition to a clot. The clots were then incubated for $18 \mathrm{hr}$. at $37^{\circ}$, after which a small volume of gelatin saline was pipetted on to each coverslip. Where the fibrin had been digested, the end-point was clearly seen by the absence of the mauve clot and the appearance of dye in the fluid. The dilution of supernatant fluid which contained 1 MLyD was thus easily estimated.

The $\mathbf{L}+$ dose, defined in the usual way as the smallest amount of staphylokinase which, when mixed with one unit of antibody, results in dissolution of the clot, was then determined. The usual procedure in which serial dilutions of the test toxin are mixed with a constant unitage of standard antitoxin was reversed, serial dilutions of a standard antiserum (Wellcome Laboratories, CPP 76/63, given an arbitrary value of 100 units anti-staphylokinase $/ \mathrm{ml}$.) at $100 \%$ differences being mixed with a constant amount of the staphylokinase preparation containing at least 4 MLyd. The technique was as follows: $0.01 \mathrm{ml}$. of each dilution of antiserum and $0.01 \mathrm{ml}$. of supernatant fluid containing $4 \mathrm{MLyD} / \mathrm{ml}$. were mixed and placed on preformed fibrin clots. The preparations were incubated at $37^{\circ}$ for $18 \mathrm{hr}$. and the results read as before. A more accurate determination of the $\mathrm{L}+$ dose was then made by decreasing the differences between the dilutions of antiserum to $20 \%$. The amount of staphylokinase/mg. bacterial dry wt. was then calculated and expressed as $L+$ units of staphylokinase/mg. bacterial dry wt.

\section{Assay of $\alpha$-haemolysin}

The $\mathrm{L}_{\mathrm{H}}$ dose was determined by mixing serial dilutions of standard antitoxin at $20 \%$ differences with a constant amount of culture supernatant fluid and adding $3 \%(v / v)$ washed rabbit red cells, using the semi-micromethod of Gladstone \& Glencross (1960). The results were related to bacterial growth and expressed as $L_{\mathbf{H}} /$ mg. bacterial dry wt.

\section{Assay of $\boldsymbol{S}$ and $\boldsymbol{F}$ components of $\boldsymbol{P} V$ leucocidin}

Woodin $(1959,1960)$ showed that PV leucocidin contained two components, $\mathrm{S}$ and $\mathrm{F}$. These were estimated by the method of Gladstone \& Glencross (1960) in which serial dilutions of antitoxin containing known arbitrary unitages of anti-F and anti-S at $\mathbf{5 0} \%$ differences were mixed with a constant volume of supernatant fluid in the presence of excess of purified $\mathbf{S}$ or $\mathbf{F}$ components respectively, and placed on preparations of human leucocytes which were examined microscopically under phase contrast. The results were expressed as $\mathrm{L}+$ units of $\mathrm{F}$ and $\mathrm{S} / \mathrm{mg}$. bacterial dry wt. 


\section{Assay of hyaluronidase}

Estimations of hyaluronidase were made by a modification of the turbidityreduction method of Pearce (1953). A standard curve was prepared by measuring the turbidity produced by different quantities of a solution of hyaluronic acid (from Dr D. Riding, Evans Biological Institute) dissolved in 0.1 M-acetate buffer ( $\mathrm{pH} \mathrm{6.0)}$ containing $0.15 \mathrm{~N}-\mathrm{NaCl}$, made up to $1 \mathrm{ml}$. with $0.2 \%(\mathrm{w} / \mathrm{v})$ gelatin acetate buffer (pH 6.0) $5 \mathrm{~min}$. after the addition of $5 \mathrm{ml}$. acidified protein reagent $(0 \cdot 1 \%, \mathrm{w} / \mathrm{v}$, bovine plasma fraction $\mathrm{V}$, Armour, in $0 \cdot 1 \mathrm{M}$-acetate buffer $\mathrm{pH} 4 \cdot 2$, adjusted to pH 3.75 with $4 \mathrm{~N}-\mathrm{HCl}$ ). All estimations were done in duplicate and the optical density at hyaluronidase concentrations of 50, 100, 150 and $200 \mu \mathrm{g} . / \mathrm{ml}$. measured before each experiment to check the slope and position of the curve.

The culture supernatant fluids were adjusted to $\mathrm{pH} 6 \cdot 0$ with $2 \mathrm{~N}-\mathrm{HCl}$ and dilutions prepared in $0 \cdot 2 \%(\mathrm{w} / \mathrm{v})$ gelatin acetate buffer $(\mathrm{pH} 6 \cdot 0)$. To $0.5 \mathrm{ml}$. of each dilution was added $0.5 \mathrm{ml}$. of the solution of hyaluronic acid containing $400 \mu \mathrm{g}$. hyaluronic acid $/ \mathrm{ml}$. in spectrophotometer tubes. These were incubated at $37^{\circ}$ for exactly $10 \mathrm{~min}$. and then transferred to a $70^{\circ}$ water-bath for $30 \mathrm{~min}$. to inactivate hyaluronidase. After the solutions had cooled to room temperature, $5 \mathrm{ml}$. acidified protein reagent were added to each tube at $1 \mathrm{~min}$. intervals, and the turbidity read after exactly $5 \mathrm{~min}$. The amount of hyaluronic acid left was read from the standard curve and the amount of hyaluronidase present calculated in turbidity reducing (t.r.) units. One t.r. unit is defined as the amount of hyaluronidase which will decrease the turbidity given by $200 \mu \mathrm{g}$. hyaluronic acid to that given by $100 \mu \mathrm{g}$. hyaluronic acid. The results were expressed as t.r. units/mg. bacterial dry wt.

\section{RESULTS}

\section{Experiments to determine the optical conditions for the production and assay of staphylokinase}

Optimal time of harvesting. Cultures were incubated at $37^{\circ}$ and $1 \mathrm{ml}$. samples taken at intervals to determine the yield of staphylokinase at different times. Graphs of growth and yield of staphylokinase against time of incubation showed that production of staphylokinase at first lagged behind growth, but then proceeded rapidly, reaching a maximum yield per $\mathrm{ml}$. at about $6 \frac{1}{2} \mathrm{hr}$. for all three strains under these conditions (Fig. 1). It was therefore decided to incubate all cultures for $6 \frac{1}{2} \mathrm{hr}$. after the $10 \%$ inoculum had been made.

Optimal time of incubation with the test fibrin clots. Six parallel series of MLyD tests were prepared and the results read after 1, 2, 4, 8, 18 and $24 \mathrm{hr}$. The longer times were used as it is known (Gerheim \& Ferguson, 1949) that staphylokinase requires long incubation to activate plasminogen. After 1 or $2 \mathrm{hr}$. of incubation no lysis had occurred and as the time was increased from 4 to $18 \mathrm{hr}$., the end-point was found in progressively higher dilutions of the supernatant fluid. Incubation beyond $18 \mathrm{hr}$. gave no further change in the end-point and all further tests were therefore incubated for this time.

Variability of results. Twenty samples of the same culture supernatant fluid were tested to see whether the staphylokinase end-point was always found in the same dilution. All the tests gave an end-point with the same dilution of antiserum or with 
one different by only $20 \%$. A series of tests with different dilutions of supernatant fluid showed that a stoichiometric relationship existed between supernatant fluid dilution and antiserum dilution (Table 1).

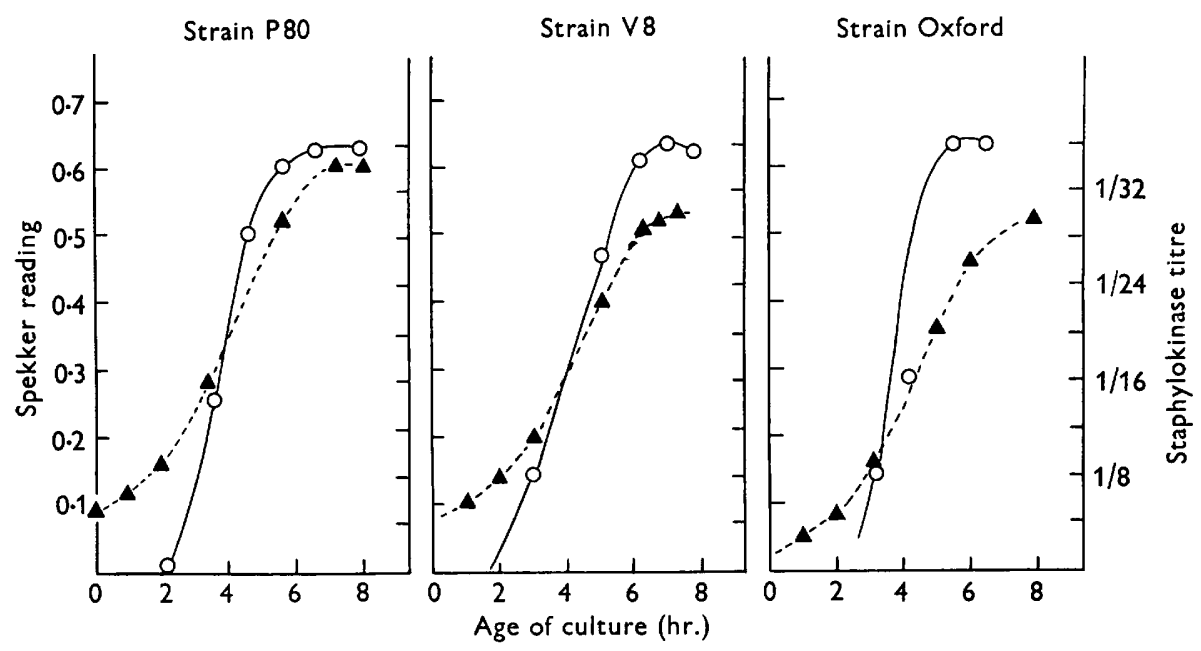

Fig. 1. Relationship between time of incubation of cultures and growth and yield of staphylokinase. $\Delta-\Delta$, growth; $\bigcirc-\bigcirc$, yield of staphylokinase.

\section{Effect of temperature on the production of staphylokinase}

Cultures were incubated at $35^{\circ}, 37^{\circ}, 39^{\circ}, 41^{\circ}$ and $43^{\circ}$ and the yields of staphylokinase assayed. Occasionally growth at $43^{\circ}$ was very low; in such cases, the cultures were discarded and new ones grown. In all other cases, the growth obtained was of the same order, i.e. about 5-6 $\mathrm{mg}$. bacterial dry wt./ml. In every test, cultures at $37^{\circ}$ were included as controls.

Table 1. $\alpha$-Haemolysin activity: relationship between dilution of supernatant fluids of staphylococcal cultures and dilutions of antiserum

\begin{tabular}{|c|c|c|c|c|c|c|c|c|}
\hline \multirow[b]{2}{*}{$\begin{array}{c}\text { Reciprocals of } \\
\text { dilutions of } \\
\text { supernatant } \\
\text { fluids }\end{array}$} & \multicolumn{8}{|c|}{ Reciprocals of dilutions of antiserum } \\
\hline & 32 & 64 & 128 & ) or & ysis ( & of clo & 2048 & 4096 \\
\hline 2 & - & - & + & + & + & + & + & + \\
\hline 4 & - & - & - & + & + & + & + & + \\
\hline 8 & - & - & - & - & + & + & + & + \\
\hline 16 & - & - & - & - & - & - & + & + \\
\hline 32 & - & - & - & - & - & - & + & + \\
\hline
\end{tabular}

The amount of staphylokinase/mg. bacterial dry wt. detected at the different temperatures was greatest at $35^{\circ}$ and smallest at $43^{\circ}$ (Fig 2). When the logarithm of the amount of staphylokinase $(y)$ was plotted against temperature $(x)$ the regression of $y$ on $x$ was linear. All three strains showed the same slope, i.e. -0.0702 $( \pm \mathbf{0 . 0 0 6 4})$ but the positions of the lines differed. The curves for strains V8 and 
Oxford were identical, while that for strain P80 was significantly lower. The coefficient 0.0702 implies that the amount of staphylokinase produced decreased by $18 \%$ for each degree rise in temperature.

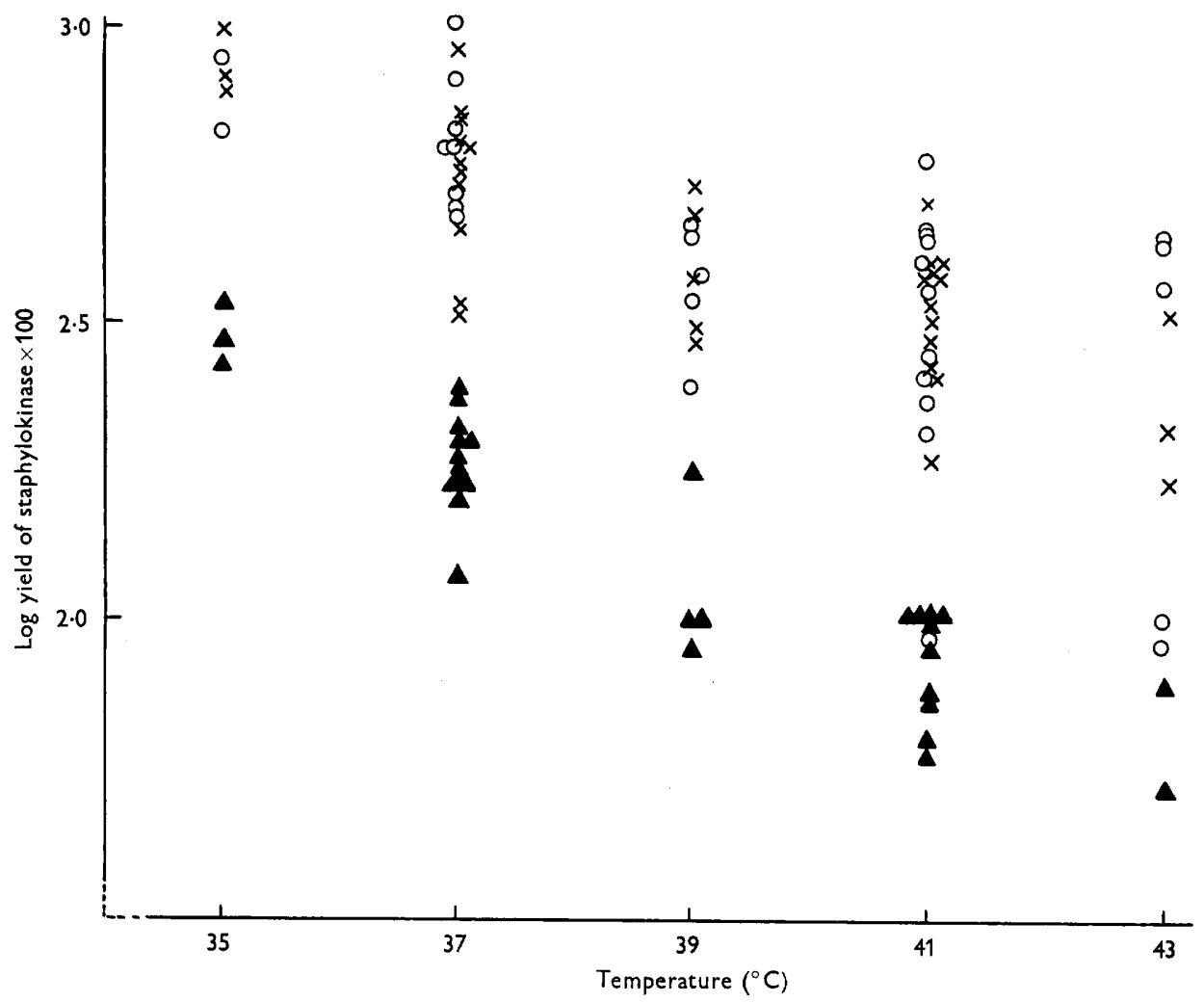

Fig. 2. Yields of staphylokinase produced by staphylococcal strains P80, V8 and Oxford at temperatures ranging from $35^{\circ}$ to $43^{\circ} . \Lambda, P 80 ; O, V 8 ; \times$, Oxford.

Several samples of supernatant fluid from cultures of all three strains at $37^{\circ}$ containing a known amount of staphylokinase were kept at $43^{\circ}$ for $6 \frac{1}{2} \mathrm{hr}$. and then re-tested. The amount of staphylokinase was unchanged and it was concluded that the lower yields obtained at the higher temperatures were not due to destruction of staphylokinase.

Effect of temperature on the production of $\alpha$-haemolysin

Cultures of the staphylococci grown at temperatures ranging from $37^{\circ}$ to $41^{\circ}$ were tested for $\alpha$-haemolysin content. The values obtained did not differ significantly at the different temperatures.

\section{Effect of temperature on the production of $\boldsymbol{F}$ and $S$ components of leucocidin}

Supernatant fluids tested for $\mathbf{F}$ and $\mathbf{S}$ components of leucocidin showed no differences in the amounts produced at the different temperatures. 


\section{Effect of temperature on the production of hyaluronidase}

Two temperatures, $37^{\circ}$ and $41^{\circ}$, were selected for these tests; a comparison of the amounts of hyaluronidase produced at these temperatures is shown in Table 2. The supernatant fluids from cultures incubated at $37^{\circ}$ contained about 5-8 times as much hyaluronidase as those incubated at $41^{\circ}$. When supernatant fluids from cultures incubated at $37^{\circ}$ were kept at $41^{\circ}$ for $14 \mathrm{hr}$, the results obtained were unchanged, showing the original difference to be due to decreased production of hyaluronidase.

Table 2. Production of hyaluronidase at $37^{\circ}$ and $41^{\circ}$

\begin{tabular}{|c|c|c|}
\hline Strain & $\begin{array}{l}\text { t.r.u. per mg. } \\
\text { at } 37^{\circ}\end{array}$ & $\begin{array}{c}\text { t.r.u. per mg. } \\
\text { at } 4.1^{\circ}\end{array}$ \\
\hline P80 & $\begin{array}{l}8 \cdot 0 \\
6 \cdot 0 \\
5 \cdot 0 \\
5 \cdot 5 \\
7 \cdot 3\end{array}$ & $\begin{array}{r}1.2 \\
<1.0 \\
<1.0 \\
1.2 \\
1.4\end{array}$ \\
\hline V8 & $\begin{array}{r}10 \cdot 7 \\
8.9 \\
7 \cdot 2 \\
>10 \cdot 0 \\
6 \cdot 7\end{array}$ & $\begin{array}{l}2 \cdot 4 \\
2 \cdot 1 \\
1 \cdot 6 \\
2 \cdot 45 \\
1 \cdot 5\end{array}$ \\
\hline Oxford & $\begin{array}{r}30 \cdot 0 \\
27 \cdot 2 \\
>13 \cdot 0 \\
19 \cdot 0 \\
17 \cdot 0\end{array}$ & $\begin{array}{l}4.8 \\
\mathbf{3} \cdot \mathbf{4} \\
\mathbf{4} \cdot \mathbf{4} \\
\mathbf{3} \cdot \mathbf{1} \\
\mathbf{2} \cdot \mathbf{5}\end{array}$ \\
\hline
\end{tabular}

\section{DISCUSSION}

The experiments described show that for these three strains of coagulase-positive staphylococci, growth at a temperature higher than $35^{\circ}$ resulted in a progressive and marked diminution in the yields of staphylokinase and hyaluronidase, while total mass of growth, $\alpha$-haemolysin and PV leucocidin remained unaltered. If it be permissible to apply these results to conditions of staphylococcal sepsis in vivo, then a rise in body temperature of this order in fever might be held to exert a suppressive effect upon staphylokinase and hyaluronidase production in the animal tissues. Even so, the role of these and other extracellular substances produced by staphylococci in relation to invasiveness and virulence is obscure. Hyaluronidase production seems unrelated to virulence for any given strain (see Bøe, 1944). The use of staphylokinase and coagulase production as indicators of staphylococcal virulence has been challenged. Kapral \& Isabel (1960) produced mutants which had lost the power to produce staphylokinase (both bound and soluble), yet these strains were as virulent for rabbits as was the parent strain. Another mutant, which retained its ability to produce coagulase, almost completely lost its invasiveness and virulence. Virulence, as many observers have suggested, is probably a complex phenomenon in which many products of the staphylococcus, some as yet unidentified, may be involved.

I wish to thank Dr G. P. Gladstone for guidance and help in this work; $\mathrm{Mr} \mathrm{J}$. Scott for the statistical analysis of the results; Drs R. A. Kekwick, D. Riding and 
A. M. Woodin for generous samples of human fibrinogen and thrombin, hyaluronic acid, and purified $\mathrm{F}$ and $\mathrm{S}$ components of leucocidin, respectively; and Miss June Tyrell and Miss Eve Cooper for their able technical assistance.

\section{REFERENCES}

BARBer, M. A. (1908). The rate of multiplication of Bacillus coli at different temperatures. J. infect. Dis. 5, 379.

BøE, J. (1944). Investigations on the Duran-Reynals spreading factor in staphylococci. Acta path. microbiol. scand. 21, 587.

Enders, J. F. \& Shaffer, M. F. (1936). Studies on natural immunity to Pneumococcus Type III. J. exp. Med. 64, 7.

Gerheim, E. B. \& Ferguson, J. H. (1949). Species reactivity to staphylokinase. Proc. Soc. exp. Biol., N.Y. 71, 261.

Gladstone, G. P. \& Fildes, P. (1940). A simple culture medium for general use without meat extract or peptone. Brit. J. exp. Path. 21, 161.

GLaDStone, G. P. \& Glencross, E. J. G. (1960). Growth and toxin production of staphylococci in cellophane sacs in vivo. Brit. J. exp. Path. 41, 313.

Gladstone, G. P. \& van Heyningen, W. E. (1957). Staphylococcal leucocidins. Brit. J. exp. Path. 38, 123.

HILls, G. M. \& SPURR, E. D. (1952). The effect of temperature on the nutritional requirements of Pasteurella pestis. J. gen. Microbiol. 6, 64.

KAPRAL, F. A. \& IsABEL, W. LL. (1960). Virulence and coagulases of Staphylococcus aureus. Proc. Soc. exp. Biol., N.Y. 104, 151.

MacCallum, P., Tolhurst, J. C., Buckle, G. \& Sissons, H. A. (1948). A new mycobacterial infection in man. J. Path. Bact. 60, 93.

Panton, P. N. \& Valentine, F. C. O. (1932). Staphylococcal toxin. Lancet, i, 506.

Paterson, J. S. (1939). Flagellar antigens of organisms of the genus Listerella. J. Path. Bact. 48, 25.

Pearce, R. H. (1953). The turbidimetric estimation of hyaluronidase. Biochem. J. 55, 467.

Preston, N. W. \& Maitland, H. B. (1952). The influence of temperature on the motility of Pasteurella pseudotuberculosis. J. gen. Microbiol. 7, 117.

Rich, A. R. \& MCKEE, C. M. (1936). The mechanism of a hitherto unexplained form of native immunity to the Type III Pneumococcus. Bull. Johns Hopk. Hosp. 59, 171.

van Heyningen, W. E. \& Gladstone, G. P. (1953). The neurotoxin of Shigella shigae. Brit. J. exp. Path. 34, 221.

Woodin, A. M. (1959). Fractionation of a leucocidin from Staphylococcus aureus. Biochem. J. 73, 225.

Woodin, A. M. (1960). Purification of the two components of leucocidin from Staphylococcus aureus. Biochem. J. 75, 158. 